\title{
LAYANAN INFORMASI BIMBINGAN KONSELING UNTUK MENINGKATKAN KOMPETENSI PEDAGOGIK PENDIDIK PAUD (PENELITIAN PADA HIMPAU DI KOTA PONTIANAK)
}

\author{
Hesty Nurrahmi
}

\begin{abstract}
Abstrak
Penelitian ini dilatarbelakangi pada beragamnya latar belakang pendidikan guru; kurangnya kemampuan guru dalam memberikan bimbingan psikologis dan fisik untuk mengembangkan potensi dan perkembangan anak usia dini; kemampuan guru dalam mengelola dan melakukan evaluasi pembelajaran (hasil pra penelitian). Metode penelitian yang digunakan yaitu metode kuantitatif dengan pendekatan eksperimen pre and post test desain, alat pegumpulan data berupa angket penilaian diri kompetensi guru PAUD. subyek penelitian guru PAUD yang terhimpun dalam HIMPAUDI Kota Pontianak. Hasil penelitian menunjukkan terdapat peningkatan non signifikant dengan kategori bervariasi pada masing-masing sub aspek kompetensi pedagogik; bentuk layanan informasi bimbingan dan konseling yang diberikan pada guru PAUD yaitu: a. Perencanaan; $b$.

Pelaksanaan; c. Evaluasi; d. Analisis hasil evaluasi ; e. Tindak lanjut ; f. Pelaporan.
\end{abstract}

Kata kunci: kompetensi pedagogik guru, layanan informasi

\section{A. Pendahuluan}

Sekolah sebagai tempat pengajaran dan pendidikan tidak dapat dipisahkan dari perkembangan peserta didik. Peserta didik merupakan salah satu unsur yang harus ada dalam pendidikan. Pendidikan dan pengajaran tidak akan mungkin sukses dan berhasil jika peserta didiknya mengalami hambatan atau kesulitan dalam perkembangan pribadinya. Bimbingan dan Konseling merupakan salah satu program yang dapat membantu penyaluran pengembangan peserta didik secara optimal. Bimbingan dan konseling diperuntukkan bagi semua orang, dari usia pra sekolah sampai lanjut usia dengan kategori normal.

Pendidikan Anak Usia Dini (PAUD) merupakan pendidikan bagi anak-anak pra sekolah yang berusia 0 - 6 tahun. Pada usia tersebut anak-anak berada masa perkembangan emas. Menurut Froebel (dalam Ernawulan 1995:3) mengungkapkan bahwa masa anak merupakan suatu fase yang sangat penting dan berharga, dan merupakan masa pembentukan dalam periode kehidupan manusia. Oleh karenanya masa anak sering dipandang sebagai masa emas (golden age) bagi penyelenggaraan pendidikan. 
Masa perkembangan yang jika difasilitasi dengan baik, maka akan dapat berkembang secara optimal. Peran orangorang disekitar anak-anak tersebut sangat diperlukan untuk tumbuh kembang mereka. Orang-orang dimaksud dapat disebut orangtua anak (ayah ibu), anggota keluarga terdekat, pengasuh, guru, pendidik, tutor (jika berada di PAUD).

Pendidik PAUD, istilah lain dari guru PAUD, mereka adalah orang-orang yang selayaknya memilki kompetensi sebagai seorang pendidik PAUD. Dalam Lampiran 2 Peraturan Menteri Pendidikan dan Kebudayaan No. 137 Tahun 2014 tentang Standar Nasional Pendidikan Anak Usia Dini (SNPAUD) memuat Kompetensi Pendidik PAUD (Guru PAUD, Guru Pendamping, dan Guru Pendamping Muda). Kompetensi yang dimaksud yaitu mencakup kompetensi pedagogik, kepribadian, sosial, dan profesional. Kompetensi Guru Pendamping mencakup kompetensi pedagogik, kepribadian, sosial, dan profesional. Kompetensi Guru Pendamping Muda mencakup pemahaman dasar-dasar pengasuhan, keterampilan melaksanakan pengasuhan, bersikap dan berperilaku sesuai dengan kebutuhan tingkat usia anak.

Kompetensi pedagogik memiliki 11 aspek, yang dijabarkan beserta sub aspek sebagai berikut:

1. Mengorganisasikan aspek perkembangan sesuai dengan karakteristik anak usia dini a. Menelaah aspek perkembangan sesuai dengan karakteristik anak usia dini

b. Mengelompokkan anak usia dini sesuai dengan kebutuhan pada berbagai aspek perkembangan

c. Mengidentifikasi kemampuan awal anak usia dini dalam berbagai bidang pengembangan

d. Mengidentifikasi kesulitan anak usia dini dalam berbagai bidang pengembangan

2. Menganalisis teori bermain sesuai aspek dan tahapan perkembangan, kebutuhan, potensi, bakat, dan minat anak usia dini

a. Memahami berbagai teori belajar dan prinsip-prinsip bermain sambil belajar yang mendidik yang terkait dengan berbagai bidang pengembangan di PAUD

b. Menelaah teori pembelajaran dalam konteks bermain dan belajar yang sesuai dengan kebutuhan aspek perkembangan anak usia dini

c. Menerapkan berbagai pendekatan, strategi, metode, dan teknik bermain sambil belajar yang bersifat holistik, sesuai kebutuhan anak usia dini, dan bemakna, yang terkait dengan berbagai bidang pengembangan di PAUD

d. Merancang kegiatan bermain sebagai bentuk pembelajaran yang mendidik pada anak usia dini 
3. Merancang kegiatan pengembangan anak usia dini berdasarkan kurikulum

a. Menyusun isi program pengembangan anak sesuai dengan tema dan kebutuhan anak usia dini pada berbagai aspek perkembangan

b. Membuat rancangan kegiatan bermain dalam bentuk program tahunan, semester, mingguan, dan harian

4. Menyelenggarakan kegiatan pengembangan yang mendidik

a. Memilih prinsip-prinsip pengembangan yang mendidik dan menyenangkan

b. Merancang kegiatan pengembangan yang mendidik dan lengkap, baik untuk kegiatan di dalam kelas, maupun luar kelas

c. Menerapkan kegiatan bermain yang bersifat holistik, autentik, dan bermakna

5. Memanfaatkan teknologi, informasi dan komunikasi untuk kepentingan penyelenggaraan kegiatan pengembangan yang mendidik

a. Memilih teknologi informasi dan komunikasi serta bahan ajar yang sesuai dengan kegiatan pengembangan anak usia dini

b. Menggunakan teknologi informasi dan komunikasi untuk meningkatkan kualitas kegiatan pengembangan yang mendidik

6. Mengembangkan potensi anak usia dini untuk pengaktualisasian diri a. Memilih sarana kegiatan dan sumber belajar pengembangan anak usia dini

b. Membuat media kegiatan pengembangan anak usia dini

c. Mengembangkan potensi dan kreatifitas anak usia dini melalui kegiatan bermain sambil belajar

7. Berkomunikasi secara efektif, empatik, dan santun

a. Memilih berbagai strategi berkomunikasi yang efektif, empatik dan santun dengan anak usia dini

b. Berkomunikasi secara efektif, empatik, dan santun dengan anak usia dini

8. Menyelenggarakan dan membuat laporan penilaian, evaluasi proses dan hasil belajar anak usia dini

a. Memahami prinsip-prinsip penilaian dan evaluasi proses dan hasil belajar anak usia dini

9. Menentukan lingkup sasaran asesmen proses dan hasil pembelajaran pada anak usia dini

a. Memilih pendekatan, metode dan teknik asesmen proses dan hasil kegiatan pengembangan pada anak usia dini

b. Menggunakan prinsip dan prosedur asesmen proses dan hasil kegiatan pengembangan anak usia dini

c. Mengadministrasikan penilaian proses dan hasil belajar secara berkesinambungan dengan menggunakan berbagai instrumen

d. Menentukan tingkat capaian perkembangan anak usia dini 
e. Menganalisis hasil penilaian proses dan hasil belajar untuk berbagai tujuan

f. Melakukan evaluasi proses dan hasil belajar

10. Menggunakan hasil penilaian, pengembangan dan evaluasi program untuk kepentingan pengembangan anak usia dini

a. Menggunakan informasi hasil penilaian dan evaluasi untuk kesinambungan belajar anak usia dini

b. Melaksanakan program remedial dan pengayaan

c. Memanfaatkan informasi hasil penilaian dan evaluasi pembelajaran untuk meningkatkan kualitas pembelajaran

d. Mengkomunikasikan hasil penilaian pengembangan dan evaluasi program kepada pemangku kepentingan

11. Melakukan tindakan reflektif, korektif dan inovatif dalam meningkatkan kualitas proses dan hasil pengembangan anak usia dini

a. Melakukan refleksi terhadap kegiatan pengembangan anak usia dini yang telah dilaksanakan

b. Meningkatkan kualitas pengembangan anak usia dini melalui penelitian tindakan kelas

c. Melakukan penelitian tindakan kelas

Uraian kompetensi pedagogik pendidik PAUD di atas mengisyaratkan bahwa begitu banyak dan detail aspek kompetensi yang selayaknya di miliki oleh seorang pendidik PAUD. Namun pada kenyataannya di lapangan, PAUD-PAUD yang berada di Kota Pontianak memiliki pendidik yang belum memiliki kompetensi pedagogik yang sesuai. Hal ini terlihat dari latar belakang pendidikan yang mereka miliki, kemampuan mengaktulisasikan kompetensi pedagogik yang mereka miliki dan kemampuan memberikan bimbingan dan pengasuhan secara psikologis dan fisik kepada anak didik mereka.

Kenyataan lain ditemukan ketika observasi awal, muatan pada program PAUD lebih dominan pada pembelajaran seperti anak sekolah dasar, padahal selayaknya untuk anak usia dini pendidikan yang dimaksud adalah pendidikan yang bermuatan bimbingan, dan permainan kepada anak.

Berdasarkan berbagai keadaan di lapangan di atas, maka sangat diperlukan penelitian tentang bagaimana peran layanan bimbingan dan konseling untuk meningkatkan kompetensi pedagogik pendidik PAUD melalui layanan informasi. Penelitian ini dilakukan pada pendidik PAUD yang terhimpun pada HIMPAUDI Kota Pontianak.

Fokus penelitian ini untuk mengetahui bentuk layanan bimbingan informasi bimbingan dan konseling untuk meningkatkan kompetensi pedagogik pendidik PAUD dan untuk mengetahui peningkatan kompetensi pedagogik pendidik PAUD

Penelitian ini dianggap penting untuk dilakukan karena membantu 
meningkatkan kompetensi pedagogik pendidik PAUD. Kompetensi pedagogik merupakan salah satu kompetensi yang mesti dimiliki pendidik PAUD. Layanan informasi bimbingan dan konseling sebagai salah satu materi yang dapat memfasilitasi peningkatan kompetensi pedagogik pendidik PAUD.

\section{B. Kajian Pustaka}

Penelitian terdahulu yang mendukung penelitian ini antara lain: Pengaruh Kompetensi Tutor Terhadap Pembelajaran Anak Usia Dini Indriya di Kabupaten Banggai oleh Nurhidaya (Guru TK Indriya Luwuk) menyatakan Penyelenggaraan PAUD menunjukkan masih belum optimal ditinjau dari standar minimal sebagaimana yang diharapkan oleh Peraturan Pemerintah Republik Indonesia Nomor 19 Tahun 2005 tentang Standar Nasional Pendidikan. Dari standar proses, pendidik belum seluruhnya membuat program pembelajaran (program tahunan, program semester, program bulanan, program mingguan maupun program harian). Padahal penyusunan program pembelajaran merupakan salah satu tugas yang mesti dilakukan yang berimplikasi pada kualitas pelaksanaan pembelajaran.

Melda (2013), penelitian tentang Kompetensi Pedagogik dan Kompetensi Profesional Guru dalam Pembelajaran di Taman Kanak-kanak (Studi Deskriptif pada Guru Taman Kanak-kanak di Kecamatan Sukasari Kota Bandung, temuan penelitian menunjukkan bahwa pada umumnya kompetensi pedagogik (meliputi aspek: pemahaman anak didik, perancangan pelaksanaan, dan evaluasi hasil belajar) dan kompetensi profesional (meliputi memahami materi, struktur, konsep, dan pola pikir keilmuan, menguasi tingkat pencapaian perkembangan, dan mengembangkan materi pembelajaran) guru TK di Kecamatan Sukasari Kota Bandung berada pada level sangat kompeten di dalam pembelajaran. Hasil penelitian ini merekomendasikan kepada guru dengan kualifikasi S1 maupun yang belum berkualifikasi s1 untuk dapat melaksanakan kegiatan pengembangan profesi melalui berbagai kegiatan pendidikan dan pelatihan tentang pembuatan media dalam pembelajaran, pengelolaan kelas yang baik, dan penyusunan alat evaluasi.

1. Layanan Informasi Bimbingan dan Konseling

a. Pengertian Layanan Informasi

Layanan informasi yaitu: layanan Bimbingan dan Konseling yang memungkinkan peserta didik (klien) menerima dan memahami berbagai informasi (seperti informasi pendidikan dan informasi jabatan) yang dapat digunakan sebagai bahan pertimbangan dan pengambilan keputusan untuk kepentingan peserta didik (klien). Klien tidak hanya peserta didik tetapi bisa juga orang tua atau wali. 
b. Keuntungan Layanan Informasi

Layanan Orientasi dan Informasi merupakan perwujudan dari fungsi pemahaman pelayanan bimbingan dan konseling. Lebih jauh layanan orientasi dan informasi akan dapat menunjang pelaksanaan fungsi-fungsi bimbingan dan konseling lainnya dalam kaitan antara bahan-bahan orientasi dan informasi itu dengan permasalahan individu. Ada tiga alasan utama "Mengapa pemberian informasi perlu diselenggarakan?"

Pertama, membekali individu dengan berbagai pengetahuan tentang lingkungan yang diperlukan untuk memecahkan masalah yang dihadapi berkenaan dengan lingkungan sekitar, pendidikan, jabatan maupun sosialbudaya. Dalam hal ini layanan informasi berusaha merangasnag individu untuk dapat secara kritis mempelajari berbagai informasi berkaitan dengan hajat hidup dan perkembangannya.

Kedua, memungkinkan individu dapat menentukan arah hidupnya,kemana dia ingin pergi. Syarat dasar untuk dapat menentukan arah hidup adalah apabila ia mengetahui apa(informasi yang harus dilakukan serta bagaimana bertindak secara kreatif dan dinamis berdasarkan atas informasi-informasi yang ada.

Ketiga, setiap idividu adalah unik.keunikan itu akan membawakan pola-pola pengambilan keputusan dan bertindak yang berbeda-beda disesuaikan dengan aspae-aspek kepribadian masing-masing individu. Dengan demikian akan terciptalah dinamika perkembangan individu dan masyarakat berdasarkan potensi positif yang ada pada diri individu dan masyarakat.

Pelayanan informasi yaitu pemberian informasi tentang berbagai hal yang dipandang bermanfaat bagi peserta didik, melalui komunikasi langsung maupun tidak langsung (melalui media cetak maupun elektronik, seperti: buku, brosur, laeflet, dan majalah

c. Metode Layanan Informasi di Sekolah

1) Ceramah

2) Diskusi

3) Karyawisata

4) Buku Panduan

5) Konferensi Karir

d. Tujuan dan Fungsi layanan Informasi Layanan informasi bertujuan untuk membekali individu dengan berbagi pengetahuan dan pemahaman tentang berbagai hal yang berguna untuk mengenal diri, merencanakan, dan mengembangkan pola kehidupan sebagai pelajar, anggota keluarga dan masyarakat. Pemahaman yang diperoleh melalui layanan informasi, digunakan sebagai bahan acuan dalam meningkatkan kegiatan dan prestasi belajar, mengembangkan 
cita-cita, menyelenggarakan kehidupan sehari-hari dalam mengambil sebuah keputusan.

e. Proses Layanan Informasi

Layanan informasi perlu direncanakan oleh konselor dengan cermat, baik mengenai informasi yang menjadi isi layanan, metode maupun media yang digunakan. Kegiatan peserta, selain mendengar dan menyimak, perlu mendapat pengarahan secukupnya. Ada enam tahapan pelaksanaan proses layanan informasi yaitu :

a) Perencanaan, kegiatan perencanaan di mulai dengan: Identifikasi kebutuhan akan informasi bagi subjek (calon) peserta layanan; Menetapkan materi informasi sebagai isi layanan; Menetapkan subject sasaran layanan; Menetapkan narasumber; Menyiapkan prosedur, perangkat dan media layanan; Menyiapkan kelengkapan administrasi

b) Pelaksanaan, kegiatan dalam tahap ini yaitu: Mengorganisasikan kegiatan layanan; Mengaktifkan peserta layanan; Mengoptimalkan peng-gunaan metode dan media.

c) Evaluasi, kegiatan evaluasi mencakup: Menetapkan materi evaluasi; Menetapkan prosedur evaluasi; Menyusun instrumen evaluasi; Mengaplikasikan instrumen evaluasi; Mengolah hasil aplikasi instrumen

d) Analisis hasil evaluasi: Menetapkan norma atau standar evaluasi; Melakukan analisis; Menafsirkan hasil analisis.

e) Tindak lanjut : Menetapkan jenis dan arah tindak lanjut; Mengkomunikasikan rencana tindak lanjut kepada pihak terkait; Melaksanakan rencana tindak lanjut

f) Pelaporan: Menyusun laporan layanan orientasi; Menyampaikan laporan kepada pihak terkait; Mendokumentasikan laporan

\section{Kompetensi Pedagogik}

Kompetensi menurut Broke and Stone (dalam Mulyasa, 2013: 62) mengemukakan bahwa kompetensi sebagai ...descriptive of qualitative nature of teacher behavior appears to be entirely meaningful. Artinya kompetensi merupakan gambaran hakikat kualitatif dari perlaku guru atau tenaga kependidikan yang tampak sangat berarti.

Kompetensi Pedagogik merupakan salah satu jenis kompetensi yang mutlak perlu dikuasai guru. Kompetensi Pedagogik pada dasarnya adalah kemampuan guru dalam mengelola pembelajaran peserta didik. Kompetensi Pedagogik merupakan kompetensi khas, yang akan membedakan guru dengan profesi 
lainnya dan akan menentukan tingkat keberhasilan proses dan hasil pembelajaran peserta didiknya. Menurut Putri dkk (2014:26) menyatakan kompetensi pedagogik dilihat dari pembelajaran yaitu kemampuan guru dalam pengelolaan pembelajaran peserta didik. Hal ini harus mampu diwujudkan oleh setiap guru untuk mencerdaskan kehidupan bangsa. Kompetensi Pedagogik, adalah kemampuan mengelola pembelajaran siswa yang meliputi pemahaman terhadap siswa, perancangan dan pelaksanaan pembelajaran, evaluasi hasil belajar, dan pengembangan siswa untuk mengaktualisasikan potensi yang dimilikinya, terinci ke dalam rumusan kompetensi sebagai berikut: (1) memahami karakteristik siswa, (2) memahami karakteristik siswa dengan kelainan fisik, sosial-emosional dan intelektual yang membutuhkan penanganan secara khusus, (3) memahami latar belakang keluarga dan masyarakat untuk menetapkan kebutuhan belajar siswa dalam konteks kebhinekaan budaya, (4) memahami cara dan kesulitan belajar siswa, (5) mampu mengembangkan potensi siswa, (6) menguasai prinsip-prinsip dasar pembelajaran yang mendidik, mengembangkan kurikulum yang mendorong keterlibatan siswa dalam pembelajaran,

(8) merancang pembelajaran yang mendidik, melaksanakan pembelajaran yang mendidik, dan (10) menilai proses dan hasil pembelajaran yang mengacu pada tujuan utuh pendidikan (Yusufhadi, 2008:71)

Kompetensi ini tidak diperoleh secara tiba-tiba tetapi melalui upaya belajar secara terus menerus dan sistematis, baik pada masa pra jabatan (pendidikan calon guru) maupun selama dalam jabatan, yang didukung oleh bakat, minat dan potensi keguruan lainnya dari masing-masing individu yang bersangkutan. Berikut adalah kompetensi pedagogik pendidik PAUD:

a. Mengorganisasikan aspek perkembangan sesuai dengan karakteristik anak usia dini

1) Menelaah aspek perkembangan sesuai dengan karakteristik anak usia dini

2) Mengelompokkan anak usia dini sesuai dengan kebutuhan pada berbagai aspek perkembangan

3) Mengidentifikasi kemampuan awal anak usia dini dalam berbagai bidang pengembangan

4) Mengidentifikasi kesulitan anak usia dani dalam berbagai bidang Pengembangan

b. Menganalisis teori bermain sesuai aspek dan tahapan perkembangan, kebutuhan, potensi, bakat, dan minat anak usia dini

1) Memahami berbagai teori belajar dan prinsip-prinsip bermain 
sambil belajar yang mendidik yang terkait dengan berbagai bidang pengembangan di PAUD

2) Menelaah teori pembelajaran dalam konteks bermain dan belajar yang sesuai dengan kebutuhan aspek perkembangan anak usia dini

3) Menerapkan berbagai pendekatan, strategi, metode, dan teknik bermain sambil belajar yang bersifat holistik, sesuai kebutuhan anak usia dini, dan bemakna, yang terkait dengan berbagai bidang pengembangan di PAUD

4) Merancang kegiatan bermain sebagai bentuk pembelajaran yang mendidik pada anak usia dini

c. Merancang kegiatan pengembangan anak usia dini berdasarkan kurikulum

1) Menyusun isi program pengembangan anak sesuai dengan tema dan kebutuhan anak usia dini pada berbagai aspek perkembangan

2) Membuat rancangan kegiatan bermain dalam bentuk program tahunan, semester, mingguan, dan harian

d. Menyelenggarakan kegiatan pengembangan yang mendidik

1) Memilih prinsip-prinsip pengembangan yang mendidik dan menyenangkan
2) Merancang kegiatan pengembangan yang mendidik dan lengkap, baik untuk kegiatan di dalam kelas, maupun luar kelas

3) Menerapkan kegiatan bermain yang bersifat holistik, autentik, dan bermakna

e. Memanfaatkan teknologi, informasi dan komunikasi untuk kepentingan penyelenggaraan kegiatan pengembangan yang mendidik

1) Memilih teknologi informasi dan komunikasi serta bahan ajar yang sesuai dengan kegiatan pengembangan anak usia dini

2) Menggunakan teknologi informasi dan komunikasi untuk meningkatkan kualitas kegiatan pengembangan yang mendidik

f. Mengembangkan potensi anak usia dini untuk pengaktualisasian diri

1) Memilih sarana kegiatan dan sumber belajar pengembangan anak usia dini

2) Membuat media kegiatan pengembangan anak usia dini

3) Mengembangkan potensi dan kreatifitas anak usia dini melalui kegiatan bermain sambil belajar

g. Berkomunikasi secara efektif, empatik, dan santun

1) Memilih berbagai strategi berkomunikasi yang efektif, empatik dan santun dengan anak usia dini 
2) Berkomunikasi secara efektif, empatik, dan santun dengan anak usia dini

h. Menyelenggarakan dan membuat laporan penilaian, evaluasi proses dan hasil belajar anak usia dini

1) Memahami prinsip-prinsip penilaian dan evaluasi proses dan hasil belajar anak usia dini

i. Menentukan lingkup sasaran asesmen proses dan hasil pembelajaran pada anak usia dini

1) Memilih pendekatan, metode dan teknik asesmen proses dan hasil kegiatan pengembangan pada anak usia dini

2) Menggunakan prinsip dan prosedur asesmen proses dan hasil kegiatan pengembangan anak usia dini

3) Mengadministrasikan penilaian proses dan hasil belajar secara berkesinambungan dengan mengunakan berbagai instrumen

4) Menentukan tingkat capaian perkembangan anak usia dini

5) Menganalisis hasil penilaian proses dan hasil belajar untuk berbagai tujuan

6) Melakukan evaluasi proses dan hasil belajar

j. Menggunakan hasil penilaian, pengembangan dan evaluasi program untuk kepentingan pengembangan anak usia dini
1) Menggunakan informasi hasil penilaian dan evaluasi untuk kesinambungan belajar anak usia dini

2) Melaksanakan program remedial dan pengayaan

3) Memanfaatkan informasi hasil penilaian dan evaluasi pembelajaran untuk meningkatkan kualitas pembelajaran

4) Mengomunikasikan hasil penilaian pengembangan dan evaluasi program kepada pemangku kepentingan

k. Melakukan tindakan reflektif, korektif dan inovatif dalam meningkatkan kualitas proses dan hasil pengembangan anak usia dini

1) Melakukan refleksi terhadap kegiatan pengembangan anak usia dini yang telah dilaksanakan

2) Meningkatkan kualitas pengembangan anak usia dini melalui penelitian tindakan kelas

3) Melakukan penelitian tindakan kelas

\section{Metode Penelitian}

Penelitian ini menggunakan metode kuantitatif dengan pendekatan eksperimen melalui desain pre-experimental design. Dikatakan demikian karena desain ini belum merupakan eksperimen sungguh-sungguh (Sugiono, 2010:109) dengan one-group Pretest-posttest design. Desain ini dapat digambarkan sebagai berikut: 


\begin{tabular}{|c|c|c|}
\hline Pre test & Intervensi & Post test \\
\hline $\mathrm{O}$ & $\mathrm{X}$ & $\mathrm{O}$ \\
& & \\
\hline
\end{tabular}

One Group Pre-Test Post test Design

Keterangan:

O1 : tes awal kelompok eksperimen

$X$ : Perlakuan (treatment, intervensi, pelatihan)

O2 : Tes akhir kelompok eksperimen

Adapun metode pengumpulan data yang digunakan adalah metode komunikasi tidak langsung dengan alat pengumpul datanya adalah angket. Angket ini digunakan saat pre test dan post test untuk mengetahui kompetensi pedagogik pendidik PAUD.

Pengumpul data berikutnya adalah tindakan eksperimen berupa penyampaian materi kepada pendidik PAUD yang telah melakukan pre test. Alat untuk tindakan eksperimen ini berupa materi yang terkait bimbingan dan konseling yang dapat meningkatkan kompetensi pedagogik pendidik PAUD.

Data penelitian ini diperoleh melalui angket sebelum dan sesudah tindakan eksperimen dilakukan. Data yang dimaksud yaitu data kompetensi pedagogik pendidik PAUD. Data lain diperoleh melalui observasi pada saat pelaksanaan layanan bimbingan dan konseling diberikan.

Sumber data dalam penelitian ini adalah pendidik PAUD yang terhimpun dalam HIMPAUDI Kota Pontianak, dengan jumlah lebih kurang 50 orang yang mewakili enam kecamatan dari berbegai PAUD yang ada di kota Pontianak. Berikut data yang terkait dengan pendidik PAUD :

\begin{tabular}{|c|c|c|c|c|}
\hline No & Nama & $\begin{array}{l}\text { Asal } \\
\text { PAUD }\end{array}$ & Pendidikan & $\begin{array}{l}\text { Menjadi } \\
\text { GURU } \\
\text { PAUD }\end{array}$ \\
\hline 1 & SA & $\begin{array}{c}\text { Bina Buah } \\
\text { Hati }\end{array}$ & SMP & 6 tahun \\
\hline 2 & MR & $\begin{array}{l}\text { Kasih } \\
\text { Bunda }\end{array}$ & D2 & 8 tahun \\
\hline 3 & SR & $\begin{array}{l}\text { Kasih } \\
\text { Bunda }\end{array}$ & SMA & 6 tahun \\
\hline 4 & PW & $\begin{array}{c}\text { Bina Buah } \\
\text { Hati }\end{array}$ & SMEA & 6 tahun \\
\hline 5 & DS & $\begin{array}{l}\text { Bina Buah } \\
\text { Hati }\end{array}$ & SMK & 3 tahun \\
\hline 6 & EY & $\begin{array}{c}\text { TPA } \\
\text { Mujahidin } \\
\end{array}$ & D2 PGTK & 9 tahun \\
\hline 7 & YN & $\begin{array}{c}\text { TPA } \\
\text { Mujahidin } \\
\end{array}$ & S1 & $\begin{array}{c}12 \\
\text { tahun }\end{array}$ \\
\hline 8 & $\mathrm{RI}$ & $\begin{array}{l}\text { KBI Al- } \\
\text { Kautsar }\end{array}$ & SMA & 3 tahun \\
\hline 9 & MT & $\begin{array}{c}\text { TPA } \\
\text { Mujahidin } \\
\end{array}$ & $\begin{array}{l}\text { S1 PG } \\
\text { PAUD }\end{array}$ & 2 tahun \\
\hline 10 & SP & $\begin{array}{c}\text { KB } \\
\text { Mujahidin }\end{array}$ & $\begin{array}{l}\text { S1 PG } \\
\text { PAUD }\end{array}$ & $\begin{array}{c}10 \\
\text { tahun }\end{array}$ \\
\hline 11 & MY & $\begin{array}{c}\text { TPA } \\
\text { Mujahidin }\end{array}$ & $\begin{array}{l}\text { S1 PG } \\
\text { PAUD }\end{array}$ & $\begin{array}{c}11 \\
\text { tahun }\end{array}$ \\
\hline 12 & NR & $\begin{array}{c}\text { TPA } \\
\text { Mujahidin }\end{array}$ & S1 & $\begin{array}{c}12 \\
\text { tahun }\end{array}$ \\
\hline 13 & HD & $\begin{array}{c}\text { TPA } \\
\text { Mujahidin }\end{array}$ & S1 & $\begin{array}{c}17 \\
\text { tahun }\end{array}$ \\
\hline 14 & HT & $\begin{array}{c}\text { KB } \\
\text { Mujahidin }\end{array}$ & D1 LPGTK & $\begin{array}{c}18 \\
\text { tahun }\end{array}$ \\
\hline 15 & MS & $\begin{array}{c}\text { KB } \\
\text { Mujahidin }\end{array}$ & S1 & $\begin{array}{l}18 \\
\text { tahun }\end{array}$ \\
\hline 16 & $\mathrm{FR}$ & $\begin{array}{c}\text { KB } \\
\text { Mujahidin }\end{array}$ & S1 & $\begin{array}{c}12 \\
\text { tahun }\end{array}$ \\
\hline 17 & $\mathrm{NL}$ & $\begin{array}{c}\text { KB } \\
\text { Harapan } \\
\text { Bangsa } \\
\end{array}$ & SMA & 5 tahun \\
\hline 18 & SY & $\begin{array}{c}\text { KB } \\
\text { Harapan } \\
\text { Bangsa } \\
\end{array}$ & SMA & 1 tahun \\
\hline 19 & DW & $\begin{array}{c}\text { LB } \\
\text { Cahaya } \\
\text { Bangsa }\end{array}$ & S1 & 2 tahun \\
\hline 20 & $\mathrm{HB}$ & $\begin{array}{c}\text { LB } \\
\text { Cahaya } \\
\text { Bangsa }\end{array}$ & SMA & 6 tahun \\
\hline 21 & FA & $\begin{array}{c}\text { LB } \\
\text { Cahaya } \\
\text { Bangsa }\end{array}$ & S1 PGSD & 6 tahun \\
\hline 22 & LF & $\begin{array}{c}\text { KB } \\
\text { Harapan } \\
\text { Bangsa }\end{array}$ & $\begin{array}{l}\text { LPG } \\
\text { PAUD }\end{array}$ & $\begin{array}{c}13 \\
\text { tahun }\end{array}$ \\
\hline 23 & SYa & Gitananda & SPG & $\begin{array}{c}20 \\
\text { tahun }\end{array}$ \\
\hline 24 & LR & Gitananda & S1 FISIP & $\begin{array}{c}20 \\
\text { tahun }\end{array}$ \\
\hline
\end{tabular}




\begin{tabular}{|c|c|c|c|c|}
\hline 25 & AS & Gitananda & SMEA & $\begin{array}{c}20 \\
\text { tahun }\end{array}$ \\
\hline 26 & $\mathrm{RD}$ & $\begin{array}{l}\text { Permata } \\
\text { Bunda }\end{array}$ & SMU & $\begin{array}{c}10 \\
\text { tahun }\end{array}$ \\
\hline 27 & RO & Sejahtera & $\begin{array}{l}\text { S1 PG } \\
\text { PAUD }\end{array}$ & $\begin{array}{c}15 \\
\text { tahun }\end{array}$ \\
\hline 28 & YA & Versa & SMA & 6 tahun \\
\hline 29 & YI & $\begin{array}{c}\text { KB } \\
\text { Miftahul } \\
\text { Ulum } \\
\end{array}$ & SMA & 3 tahun \\
\hline 30 & CJ & $\begin{array}{c}\text { KB } \\
\text { Miftahul } \\
\text { Ulum }\end{array}$ & SMA & 9 tahun \\
\hline 31 & $\mathrm{TN}$ & $\begin{array}{c}\text { KB } \\
\text { Miftahul } \\
\text { Ulum }\end{array}$ & $\begin{array}{c}\text { S1 } \\
\text { Pendidikan }\end{array}$ & $\begin{array}{c}10 \\
\text { tahun }\end{array}$ \\
\hline 32 & LS & Mentari & SMK & 6 tahun \\
\hline 33 & VN & AL-Barqie & LPGTK & 6 tahun \\
\hline 34 & $\mathrm{SH}$ & Srikandi & D3 & 7 tahun \\
\hline 35 & $\mathrm{ML}$ & $\begin{array}{c}\text { Harapan } \\
\text { Bangsa }\end{array}$ & S1 PAUD & 8 tahun \\
\hline 36 & $\mathrm{SI}$ & Mentari & LPGTK & 8 tahun \\
\hline 37 & SY & Al-Barqie & SMA & 2 tahun \\
\hline 38 & $\mathrm{EF}$ & $\begin{array}{l}\text { Kasih } \\
\text { Bunda }\end{array}$ & D2 PGTK & 4 tahun \\
\hline 39 & $\mathrm{RS}$ & $\begin{array}{l}\text { Kasih } \\
\text { Bunda }\end{array}$ & $\begin{array}{l}\text { S1 PG } \\
\text { PAUD }\end{array}$ & 8 tahun \\
\hline 40 & NR & $\begin{array}{c}\text { KB } \\
\text { Harapan } \\
\text { Bangsa }\end{array}$ & PG PAUD & $\begin{array}{c}12 \\
\text { tahun }\end{array}$ \\
\hline 41 & LS & Gitananda & SMA & $\begin{array}{c}20 \\
\text { tahun }\end{array}$ \\
\hline 42 & $\mathrm{CR}$ & $\begin{array}{c}\text { Bina Buah } \\
\text { Hati }\end{array}$ & S1 & 3 tahun \\
\hline 43 & IF & $\begin{array}{l}\text { KBI Al- } \\
\text { Kautsar }\end{array}$ & $\begin{array}{l}\text { SI PG } \\
\text { PAUD }\end{array}$ & 1 tahun \\
\hline 44 & $M Q$ & $\begin{array}{c}\text { Ikhwanul } \\
\text { Qarib }\end{array}$ & $\begin{array}{l}\text { MA Darul } \\
\text { Ulum }\end{array}$ & 3 bulan \\
\hline 45 & ST & $\begin{array}{l}\text { Kasih } \\
\text { Bunda }\end{array}$ & MAN & 9 tahun \\
\hline 46 & SM & $\begin{array}{l}\text { Kasih } \\
\text { Bunda }\end{array}$ & S1 & 8 tahun \\
\hline 47 & HD & PKK BML & S1 & $\begin{array}{c}10 \\
\text { tahun }\end{array}$ \\
\hline
\end{tabular}

Angket sebagai alat pengumpul data penelitian yang diberikan pada responden, responden yang dimaksud yaitu pendidik PAUD. Angket yang dimaksud yaitu angket penilaian diri kompetensi pedagogik. Pemilihan dengan model angket ini, didasarkan atas alasan bahwa: (a) responden memiliki waktu untuk menjawab pernyataan-pernyataan, (b) setiap responden menghadapi susunan dan cara pengisian yang sama atas pernyataan yang diajukan, (c) responden mempunyai kebebasan memberikan jawaban, dan (d) dapat digunakan untuk mengumpulkan data atau keterangan dari banyak responden dan dalam waktu yang tepat. Melalui teknik model angket ini akan dikumpulkan data yang berupa jawaban tertulis dari responden atas sejumlah pernyataan yang diajukan di dalam angket tersebut.

Analisis dan pengolahan data yang digunakan dalam penelitian ini menggunakan perhitungan persentase. Adapun rumus perhitungan persentase yang digunakan dalam penelitian yaitu sebagai berikut:

$$
\mathrm{X} \%=\frac{\Sigma \text { skor aktual }}{\sum \text { skor maksimal ideal }} \times 100 \%
$$

\section{Keterangan:}

$X \%$ : Persentase yang dicapai

$\Sigma$ skor actual: Skor yang didapat dari hasil jawaban responden

$\Sigma$ skor maksimum ideal: Skor tertinggi yang dicapai

Sebelum dilakukan analisis hasil angket, maka dilakukan perhitungan kriteria interpretasi skor. Kategori interpretasi skor dibagi menjadi tiga, yakni "tinggi", "sedang", dan "rendah". Penentuan daerah tiap kategori dilakukan dengan perhitungan sebagai berikut: 
a. Jawaban selalu/setiap kegiatan mempunyai skor 3 , maka $3 \times 50=150$ $\rightarrow 100 \%$

b. Jawaban kadang-kadang/sesuai keperluan mempunyai skor 2 , maka $2 \mathrm{x}$ $50=100 \rightarrow 50 \%$

c. Jawaban belum mempunyai skor 1 , maka $1 \times 50=100 \rightarrow 25 \%$

Jarak dari jawaban pernyataan selalu/ setiap kegiatan dan belum adalah 100 atau $50 \%$. Selanjutnya angket tersebut dibagi 3, untuk membuat 3 kategori kriteria interpretasi skor. 100: 3 = 33.33atau 75\%: 3 $=25 \%$, artinya jarak antara nilai terendah dan tertinggi pada tiap kategori adalah sebesar 50 atau $25 \%$.

Kategori Interpretasi Skor

\begin{tabular}{|c|c|c|}
\hline Rentang & Kategori & $\begin{array}{c}\text { RentangPe } \\
\text { rsentase }\end{array}$ \\
\hline $100>X \geq 150$ & Tinggi & $\begin{array}{c}66,67 \%- \\
100 \%\end{array}$ \\
\hline $50>X \geq 99$ & Sedang & $\begin{array}{c}33,33 \%- \\
66,66 \%\end{array}$ \\
\hline $0>X \geq 49$ & Rendah & $\begin{array}{c}0,00 \%- \\
33,32 \%\end{array}$ \\
\hline
\end{tabular}

Analisis peningkatan kompetensi pedagogik guru PAUD berasal dari nilai pretest dan postest dapat menggunakan skor gain yang dinormalisasi. Gain yang dinormalisasi dapat dihitung menggunakan rumus gain score ternormalisasi dengan rumus sebagai berikut:

$$
<\mathrm{g}>=\frac{(\%<S f>-\%<S i>)}{(100 \%-\%<S i>)}
$$

Keterangan

$S_{f} \quad=$ Skor postest (final score)

$\mathrm{Si}=$ Skor pretest (initial score) $100 \%=$ Konstanta

(Hake, 1999).
Gain adalah selisih antara nilai postest dan pretest, gain menunjukkan peningkatan kompetensi pedagogik PAUD.

Kelebihan penggunaan dalam meningkatkan kompetensi ditinjau berdasarkan perbandingan nilai gain yang dinormalisasi (N-gain), antara kelompok eksperimen melalui data pretest dan posttest.

\section{Hasil Penelitian}

Hasil penelitian menunjukkan:

1. Kompetensi Pedagogik Pendidik PAUD Rekapitulasi Hasil Kompetensi Pedagogik Pendidik PAUD per Aspek

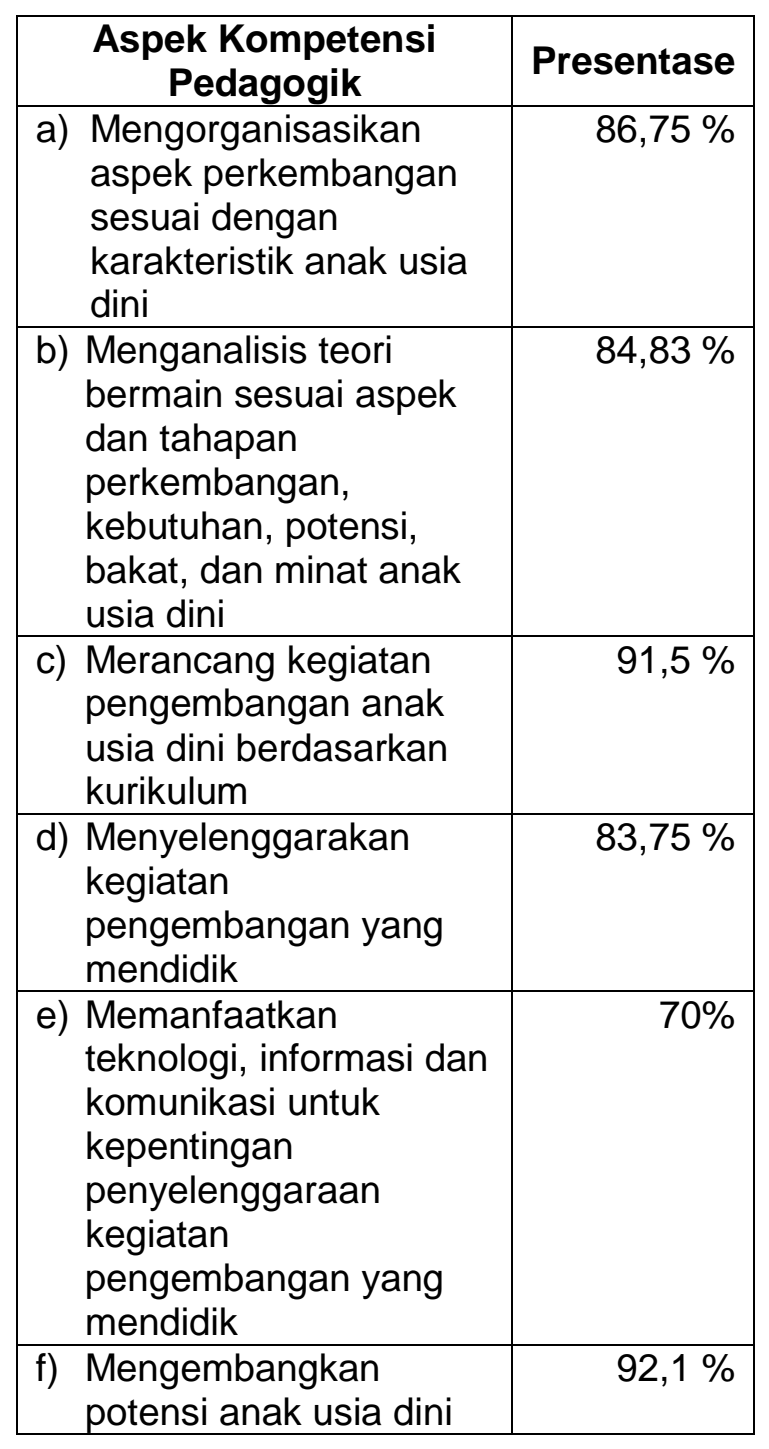




\begin{tabular}{|c|c|}
\hline $\begin{array}{l}\text { untuk } \\
\text { pengaktualisasian diri }\end{array}$ & \\
\hline $\begin{array}{l}\text { g) Berkomunikasi secara } \\
\text { efektif, empatik, dan } \\
\text { santun }\end{array}$ & $95 \%$ \\
\hline $\begin{array}{l}\text { h) Menyelenggarakan dan } \\
\text { membuat laporan } \\
\text { penilaian, evaluasi } \\
\text { proses dan hasil belajar } \\
\text { anak usia dini }\end{array}$ & $91,5 \%$ \\
\hline $\begin{array}{l}\text { i) Menentukan lingkup } \\
\text { sasaran asesmen } \\
\text { proses dan hasil } \\
\text { pembelajaran pada } \\
\text { anak usia dini }\end{array}$ & $80,6 \%$ \\
\hline $\begin{array}{l}\text { j) Menggunakan hasil } \\
\text { penilaian, } \\
\text { pengembangan dan } \\
\text { evaluasi program untuk } \\
\text { kepentingan } \\
\text { pengembangan anak } \\
\text { usia dini }\end{array}$ & $76,8 \%$ \\
\hline $\begin{array}{l}\text { k) Melakukan tindakan } \\
\text { reflektif, korektif dan } \\
\text { inovatif dalam } \\
\text { meningkatkan kualitas } \\
\text { proses dan hasil } \\
\text { pengembangan anak } \\
\text { usia dini }\end{array}$ & $59,72 \%$ \\
\hline
\end{tabular}

Berdasarkan tabel diatas dapat dijabarkan sebagai berikut:

a. Kegiatan guru PAUD dalam mengorganisasikan aspek perkembangan sesuai dengan karakteristik anak usia dini seperti: menelaah aspek perkembangan sesuai dengan karakteristik anak usia dini; mengelompokkan anak usia dini sesuai dengan kebutuhan pada berbagai aspek perkembangan; mengidentifikasi kemampuan awal anak usia dini dalam berbagai bidang pengembangan; dan mengidentifikasi kesulitan anak usia dini dalam berbagai bidang pengembangan tergolong tinggi yaitu mencapai $86,75 \%$.

b. Kegiatan guru PAUD dalam menganalisis teori bermain sesuai aspek dan tahapan perkembangan, kebutuhan, potensi, bakat, dan minat anak usia dini seperti: memahami berbagai teori belajar dan prinsip-prinsip bermain sambil belajar yang mendidik yang terkait dengan berbagai bidang pengembangan di PAUD; menelaah teori pembelajaran dalam konteks bermain dan belajar yang sesuai dengan kebutuhan aspek perkembangan anak usia dini; menerapkan berbagai pendekatan, strategi, metode, dan teknik bermain sambil belajar yang bersifat holistik, sesuai kebutuhan anak usia dini, dan bemakna, yang terkait dengan berbagai bidang pengembangan di PAUD; dan merancang kegiatan bermain sebagai bentuk pembelajaran yang mendidik pada anak usia dini dengan skor $84,83 \%$

c. Kegiatan guru PAUD dalam merancang kegiatan pengembangan anak usia dini berdasarkan kurikulum dimulai dengan: menyusun isi program pengembangan anak sesuai dengan tema dan kebutuhan anak usia dini pada berbagai aspek perkembangan dan membuat rancangan kegiatan bermain dalam bentuk program tahunan, semester, mingguan, dan harian mencapai $91,5 \%$

d. Kegiatan guru PAUD dalam menyelenggarakan kegiatan pengembangan yang mendidik seperti: memilih prinsip-prinsip 
pengembangan yang mendidik dan menyenangkan; merancang kegiatan pengembangan yang mendidik dan lengkap, baik untuk kegiatan di dalam kelas, maupun luar kelas; dan menerapkan kegiatan bermain yang bersifat holistik, autentik, dan bermakna memperoleh skor $83,75 \%$

e. Kegiatan guru PAUD dalam memanfaatkan teknologi, informasi dan komunikasi untuk kepentingan penyelenggaraan kegiatan pengembangan yang mendidik yaitu: memilih teknologi informasi dan komunikasi serta bahan ajar yang sesuai dengan kegiatan pengembangan anak usia dini dan menggunakan teknologi informasi dan komunikasi untuk meningkatkan kualitas kegiatan pengembangan yang mendidik tergolong $70 \%$

f. Kegiatan guru PAUD dalam mengembangkan potensi anak usia dini untuk pengaktualisasian diri seperti: memilih sarana kegiatan dan sumber belajar pengembangan anak usia dini; membuat media kegiatan pengembangan anak usia dini; dan mengembangkan potensi dan kreatifitas anak usia dini melalui kegiatan bermain sambil belajar mencapai $92,1 \%$

g. Kegiatan guru PAUD dalam berkomunikasi secara efektif, empatik, dan santun seperti: memilih berbagai strategi berkomunikasi yang efektif, empatik dan santun dengan anak usia dini; berkomunikasi secara efektif, empatik, dan santun dengan anak usia dini mencapai $95 \%$

h. Kegiatan guru PAUD untuk menyelenggarakan dan membuat laporan penilaian, evaluasi proses dan hasil belajar anak usia dini: memahami prinsip-prinsip penilaian dan evaluasi proses dan hasil belajar anak usia dini mencapai $91,5 \%$

i. Kegiatan guru PAUD dalam menentukan lingkup sasaran asesmen proses dan hasil pembelajaran pada anak usia dini seperti: memilih pendekatan, metode dan teknik asesmen proses dan hasil kegiatan pengembangan pada anak usia dini; menggunakan prinsip dan prosedur asesmen proses dan hasil kegiatan pengembangan anak usia dini; mengadministrasikan penilaian proses dan hasil belajar secara berkesinambungan dengan menggunakan berbagai instrument; menentukan tingkat capaian perkembangan anak usia dini, menganalisis hasil penilaian proses dan hasil belajar untuk berbagai tujuan; melakukan evaluasi proses dan hasil belajar memperoleh skor $80,6 \%$

j. Kegiatan guru PAUD dalam menggunakan hasil penilaian, pengembangan dan evaluasi program untuk kepentingan pengembangan anak usia dini yaitu menggunakan informasi hasil penilaian dan evaluasi untuk kesinambungan belajar anak usia dini; melaksanakan program remedial dan pengayaan; memanfaatkan informasi hasil penilaian dan 
evaluasi pembelajaran untuk meningkatkan kualitas pembelajaran; mengkomunikasikan hasil penilaian pengembangan dan evaluasi program kepada pemangku kepentingan mencapai skor $76,8 \%$

k. Kegiatan guru PAUD dalam melakukan tindakan reflektif, korektif dan inovatif dalam meningkatkan kualitas proses dan hasil pengembangan anak usia dini yaitu: melakukan refleksi terhadap kegiatan pengembangan anak usia dini yang telah dilaksanakan; meningkatkan kualitas pengembangan anak usia dini melalui penelitian tindakan kelas; melakukan penelitian tindakan kelas mencapai skor $59,72 \%$.

2. Bentuk Layanan informasi bimbingan dan konseling untuk meningkatkan kompetensi pedagogik pendidik PAUD se Kota Pontianak

Kegiatan bimbingan konseling pada guru PAUD berupa layanan informasi dilakukan pada tiga sesi, sesi pertama menyampaikan maksud dan tujuan kegiatan penelitian sekaligus menyampaikan angket penelitian untuk mengetahui profile guru PAUD. Hasil angket diolah kemudian diketahui sub aspek kompetensi pedagogik yang perlu untuk diberikan penguatan berupa layanan informasi.

Berdasarkan data hasil angket, maka peneliti melakukan kegiatan sesi kedua, penyampaian materi yaitu Layanan Informasi Bimbingan dan Konseling untuk membantu sub kompetensi point $\mathrm{e}$, j, dan k. Pada sesi ini dilakukan melalui prosedur kegiatan sebagai berikut: pertama, peneliti memberikan appersepsi pada materi yang akan disampaikan, ini disambut peserta (guru PAUD) dengan aktif. Kedua, peneliti menyampaikan materi: 1) Memanfaatkan teknologi, informasi dan komunikasi untuk kepentingan penyelenggaraan kegiatan pengembangan; 2) Menggunakan hasil penilaian, pengembangan dan evaluasi program untuk kepentingan pengembangan anak usia dini; 3) Melakukan tindakan reflektif, korektif dan inovatif dalam meningkatkan kualitas proses dan hasil pengembangan anak usia dini.

Layanan informasi pada sesi kedua ini diselenggarakan secara klasikal, melalui ceramah dengan alat peraga power point yang ditayangkan lewat infokus, selanjutnya dilakukan tanya jawab (sharing), dan diskusi. Ada enam tahapan pelaksanaan proses layanan informasi yaitu:

a. Perencanaan; dimulai dengan mengidentifikasi kebutuhan akan informasi bagi subjek (calon) peserta layanan, disini peneliti menggunakan pretest melalui angket. Setelah hasil angket terkumpul dapatlah data materi mana yang perlu disampaikan, sehingga ditetapkanlah tiga materi informasi yang akan disampaikan. Kemudian menetapkan dan menghuhungi narasumber yang sesuai dengan keahlian; selanjutnya menyiapkan 
prosedur, perangkat dan media layanan yang diperlukan serta menyiapkan kelengkapan administrasi seperti surat undangan, daftar hadir, alat tulis dan sebaginya yang diperlukan.

b. Pelaksanaan, kegiatan ini meliputi: mengorganisasikan kegiatan layanan informasi yang diselenggarakan dari awal pelaksanaan sampai selesai, melibatkan peserta utuk aktif dan mengoptimalkan penggunaan metode dan media yang tersedia.

c. Evaluasi, setelah materi informasi disampaikan ke guru-guru PAUD, di akhir sesi dilakukan evaluasi (post test) tentang materi yang telah disampaikan, menyampaikan prosedur evaluasi, setelah data terkumpul kemudian melakukan pengolahan hasil.

d. Analisis hasil evaluasi
1) Menetapkan norma atau standar evaluasi
2) Melakukan analisis
3) Menafsirkan hasil analisis

e. Tindak lanjut
1) Menetapkan jenis dan arah tindak lanjut
2) Mengkomunikasikan rencana tindak lanjut kepada pihak terkait
3) Melaksanakan rencana tindak lanjut

f. Pelaporan
1) Menyusun laporan layanan orientasi
2) Menyampaikan laporan kepada pihak terkait
3) Mendokumentasikan laporan

\section{E. Penutup}

Berdasarkan hasil penelitian dapat disimpulkan bahwa layanan informasi dalam meningkatkan kompetensi pedagogik guru PAUD se Kota Pontianak, dapat diuraikan sebagai berikut:

1. Kompetensi pedagogik guru PAUD se Kota Pontianak berdasarkan hasil penelitian yaitu terdapat peningkatan yang non signifikant dengan kategori bervariasi pada sub aspek kompetensi pedagogik guru PAUD.

2. Bentuk layanan informasi bimbingan dan konseling untuk meningkatkan kompetensi pedagogik pendidik PAUD se Kota Pontianak yaitu dimulai dari: a. Perencanaan; b. Pelaksanaan; c. Evaluasi; d. Analisis hasil evaluasi ; e. Tindak lanjut ; dan diakhiri dengan $f$. Pelaporan

Penelitian ini menyampaikan saran : a. guru PAUD, hendaknya bersifat terbuka dan aktif dalam mencari informasi baru dan terbuka pada kelemahan yang dimiliki; b. pengelola PAUD, hendaknya memberi jam khusus bimbingan dan konseling; c.lembaga peneliti dan dosen bimbingan dan konseling hendaknya memberikan pelatihan dan pendampingan dalam kegiatan bimbingan dan konseling.

\section{F. Daftar Pustaka}

Ernawulan Saodih, (1995) Psikologi Perkembangan, Makalah On line Hake, Richard R. (1999). Analyzing Change/Gain Scores. (Online), 
(http://

www.physics.indiana.edu/ sdi/Analyz ingChange-Gain.pdf, diakses tanggal 16 Juli 2013)

Melda (2013), Kompetensi Pedagogik dan Kompetensi Profesional Guru dalam Pembelajaran di Taman Kanak-kanak (Studi Deskriptif pada Guru Taman Kanak-kanak di Kecamatan Sukasari Kota Bandung

Mulyasa, (2013), Uji Kompetensi dan Penilaian Kinerja Guru, Bandung: Remaja Rosdakarya

Nurhidaya,(....) Pengaruh Kompetensi Tutor Terhadap Pembelajaran Anak Usia Dini Indriya Di Kabupaten Banggai

Permendikbud No. 137 Tahun 2014 (Lampiran 1) Standar Isi PAUD

Putri Balqis Dkk , 2014 Kompetensi Pedagogik Guru Dalam Meningkatkan Motivasi Belajar Siswa Pada SMPN 3 Ingin Jaya Kabupaten Aceh Besar: Jurnal Administrasi Pendidikan, Issn 2302-0156 Pascasarjana Universitas Syiah Kuala 14 Pages

Pp. 25- 38

Prayitno, (1999), Panduan Kegiatan pengawasan Bimbingan dan Konseling di sekolah. Jakarta: PT Asdi Mahasatya.

Sugiyono. (2010), Metode penelitian pendidikan.Bandung: Alfabeta.
Yusufhadi Miarso, (2008), Peningkatan Kualifikasi Guru dalam Perspektif Teknologi Pendidikan, Jurnal Pendidikan PENABUR

http://www.jamarismelayu.com/2014/12/k ompetensi-guru-paud-gurupendamping.html

http://paud-

anakbermainbelajar.blogspot.co.id /2014/10/standar-kompetensiguru-dan-pendidik.html

http://agusnurhuda82.blogspot.co.id/2013/ 05/layanan-informasi $9 . \mathrm{html}$ https://wahid07.wordpress.com/2011/09/2 8/layanan-informasi-dalambimbingan-konseling/ 